Short communication

\title{
COMPARISON OF M.SEMITENDINOSUS MORPHOMETRY AND STRUCTURE IN GILTS AND BARROWS AT MARKET AGE
}

\author{
BOŽIČKOVIĆ Ivana ${ }^{1 *}$, VITOROVIĆ Duškoํ르, BLAGOJEVIĆ Miloš², NEŠIĆ Ivana ${ }^{2}$, \\ JOVIĆ Slavoljub², ZDRAVKOVIĆ Marija ${ }^{3}$, BRKIĆ Zlata ${ }^{4}$
}

${ }^{1}$ University of Belgrade, Faculty of Agriculture, Department of Animal Science, Nemanjina 6, 11080 Zemun-Belgrade, Serbia; ${ }^{2}$ University of Belgrade, Faculty of Veterinary Medicine, Department of Anatomy, Department of Physiology and Biochemistry, Bulevar Oslobođenja 18, 11000 Belgrade, Serbia; ${ }^{3}$ University of Belgrade, Faculty of Medicine, Medical Center Bezanijska Kosa, Bezanijska Kosa bb, 11080 Zemun-Belgrade, Serbia; ${ }^{4}$ Militarymedicine Academy, Crnotravska 17, 11000 Belgrade, Serbia

(Received 25 May; Accepted 26 October 2015)

The aim of this paper was to investigate the differences in morphometric characteristics and histological structure of $m$. semitendinosus, between gilts and barrows of German Landrace breed at the end of the fattening period. Morphometric characteristics (weight, length, diameter and cross sectional area) of $m$. semitendinosus were not significantly different, while gender as a factor influenced the histological properties of this muscle. A very high statistical difference $(\mathrm{p}<0.01)$ in the total number of muscle fibers in $m$. semitendinosus was determined, with gilts having a higher total fiber number. The cross sectional area of fast twitch oxidative (FTO) fibers was significantly higher $(\mathrm{p}<0.05)$ in barrows. Gender did not affect the distribution of different fiber types: in both gender, the most present fiber types (48-52\%) were fast twitch glycolitic (FTG), FTO fibers represented $27-30 \%$ of the total fiber number, while slow twitch oxidative fibers (STO) were the least represented $(\approx 20 \%)$.

Key words: gender, fiber types, muscle composition, fattening, pigs

\section{INTRODUCTION}

Skeletal muscles of adult pigs consist of different types of muscle fibers. Based on ATPase activity, speed of contraction, color and type of metabolism three muscle fiber types could be defined: red, slow twitch oxidative (STO); red, fast twitch oxidative (FTO) and white, fast twitch oxidative (FTG) [1]. The distribution of these fiber types differs in skeletal muscles of the same individual [2,3]. It is therefore possible to define red and white muscles in pigs [4]. Red, dark muscles consist of a higher number of STO and FTO fibers, while in white muscles FTG fibers are dominant. The results on the influence of gender on the number and distribution of fibers within the muscle are contradictory. Some authors $[5,6]$ point out that gender has no influence on the

\footnotetext{
*Corresponding author: e-mail: ivadamo@agrif.bg.ac.rs
} 
distribution of different muscle fiber types. Other authors [7-9] consider gender as a factor affecting the diameter of muscle fibers, with gilts having fibers of a smaller diameter compared to barrows. On the contrary, there are data indicating a larger diameter and fiber girth in gilts compared to barrows [10-12].

The aim of this study was to investigate the differences in structure of m. semitendinosus, both morphometrical (weight, length, diameter and cross sectional area) and histological properties (total number of fibers, fiber diameter, distribution of muscle fiber types) of $m$. semitendinosus, between gilts and barrows of German Landrace breed at the end of fattening.

\section{MATERIAL AND METHODS}

\section{Animals and feeding}

The research was conducted at the experimental station of the Leibnitz Institute for Farm Animal Biology - FBN Dummerstorf, Rostock, Germany. Pigs of German Landrace breed were used for the investigation. All procedures including the use and treatment of animals were in accordance with the guidelines set by the Animal Care Committee of the State Mecklenburg-Vorpommern, Germany, based on the German Law of Animal Protection. Eight multiparous sows were bred to the same German Landrace boar. Sow pregnancy was confirmed at day 28 of gestation by ultrasound. The sows were housed individually, under controlled environmental conditions (temperature $19^{\circ} \mathrm{C}$, relative humidity $60-80 \%$ ). All animals had free access to water, and were manually fed twice a day with standard soy based concentrate (Denkavit, Trede\&Pein GmbH\&Co. KG, Itzehohe, Germany). To induce farrowing, on day 114 of pregnancy all sows were injected intramuscularly with $1 \mathrm{ml}$ of a synthetic prostaglandin (cloprostenol, $75 \mathrm{mg} / \mathrm{ml}$ : AniMedica West, Chemische Produkte $\mathrm{GmbH}$, Senden, Germany). After birth, the body weight of piglets was recorded. Male piglets were castrated at day 5 after birth, and all piglets were weaned at day 28 of age. During the whole growing-finishing period the offspring was fed ad libitum, with standard commercial starter, grower and finisher feed mixtures. The growing period lasted until 180 days of age, and average market weight of slaughter pigs at the end of fattening was $108.35 \mathrm{~kg}$.

\section{Muscle histology and histochemistry}

For histological and histochemical analysis, the left side $m$. semitendinosus was used. Two samples were taken from $m$. semitendinosus of each individual: one sample was taken from the deep dark portion of the mid belly, and the second sample was taken from the superficial light portion of the mid belly. Pieces of the muscle were mounted on cork-chucks and snap frozen in liquid nitrogen. Serial sections were cut at $10 \mu \mathrm{m}$ in a cryostat, and stained for cytoplasm and nuclei by hematoxylin/eosin [13], or exposed to a combined reaction for NADH-tetrazolium reductase (NADH-TR) [14] and acid preincubated ATPase at $\mathrm{pH}$ 4,2 [15], which enables to classify STO, FTO and FTG 
muscle fibers. Further image analysis of sections of adult pig muscle was done by AMBA software (AMBA, IBSB, Berlin, Germany). On hematoxylin/eosin stained sections the number of fibers and cross sectional area (FCSA) of individual fibers were determined first, and immediately afterwards the sections stained for fiber types were analyzed. The average values of the investigated parameters calculated from both regions of the muscle were taken for further analysis. TFN was calculated by multiplying the number of fibers/unit area with FCSA.

\section{Statistical analysis}

Data were subjected to analysis of variance using the GLM and mixed classification models of SAS (SAS System for Windows Release 8e, SAS Institute Inc., Cary, NC 27513, USA).

\section{RESULTS AND DISCUSSION}

The data on morphometric characteristics of $m$. semitendinosus are shown in Table 1. Gender did not influence birth weight. However, body weight at the end of fattening was significantly higher $(\mathrm{p}<0.05)$ in barrows.

Table 1. Body weight and m.semitendinosus morphometric traits in German Landrace pigs of different gender $(\mathrm{LSM} \pm \mathrm{SE})$

\begin{tabular}{lccc}
\hline \multirow{2}{*}{ Trait } & \multicolumn{2}{c}{ Gender } & \multirow{2}{*}{ P value } \\
\cline { 2 - 3 } & Barrows (n=16) & Gilts $(\mathbf{n}=\mathbf{1 5})$ & \\
\hline Birth weight, $\mathrm{kg}$ & $1.38 \pm 0.04$ & $1.22 \pm 0.03$ & 0.20 \\
Slaughter weight, $\mathrm{kg}$ & $108.17 \pm 1.96$ & $103.27 \pm 0.18$ & 0.05 \\
\hline Morphometric properties of & $\mathrm{m}$. semitendinosus & & \\
Weight, g & $455.14 \pm 23.45$ & $487.69 \pm 22.95$ & 0.12 \\
Length, cm & $22.98 \pm 0.63$ & $24.02 \pm 0.62$ & 0.21 \\
Girth, cm & $21.20 \pm 0.45$ & $21.59 \pm 0.44$ & 0.35 \\
\hline Cross sectional area, $\mathrm{cm}^{2}$ & $35.88 \pm 1.47$ & $37.16 \pm 1.44$ & 0.37 \\
\hline
\end{tabular}

Morphometric characteristics of $m$. semitendinosus (weight, length, girth and cross sectional area), were not significantly different between gilts and barrows, although all of the observed measurements were higher in gilts.

A high statistical difference $(\mathrm{p}<0.01)$ in total fiber number in $m$. semitendinosus was observed in gilts compared to barrows (Table 2).

Both in gilts and in barrows, the most abundant fibers in the muscle were of FTG type (48-52\%). FTO fibers represented $27-30 \%$ of total fiber number, while the least represented were fibers of STO type $(\approx 20 \%)$. The cross sectional area of FTO 
fibers was significantly higher $(\mathrm{p}<0.05)$ in barrows. For STO and FTG fiber types no statistically significant differences were recorded.

Table 2. Effects of gender on muscle fiber number, fiber type distribution (\%) and fiber cross sectional area $\left(\mu \mathrm{m}^{2}\right)$ of m.semitendinosus in German landrace pigs at market weight (LSM $\pm \mathrm{SE}$ )

\begin{tabular}{lccc}
\hline \multirow{2}{*}{ Trait } & \multicolumn{2}{c}{ Gender } & \multirow{2}{*}{ P value } \\
\cline { 2 - 3 } & Barrows $(\mathbf{n}=\mathbf{1 5})$ & Gilts $(\mathbf{n}=\mathbf{1 4})$ & \\
\hline Total fiber number & $876271 \pm 49222.00$ & $1014734 \pm 47407.00$ & 0.01 \\
\hline STO fibers, $\%$ & $20.68 \pm 1.20$ & $20.23 \pm 1.16$ & 0.77 \\
\hline FTO fibers, \% & $30.03 \pm 1.75$ & $26.98 \pm 1.68$ & 0.12 \\
\hline FTG fibers, $\%$ & $48.19 \pm 1.83$ & $51.78 \pm 1.76$ & 0.11 \\
\hline STO fiber area, $\mu \mathrm{m}^{2}$ & $4712.89 \pm 414.36$ & $4257.16 \pm 400.75$ & 0.22 \\
\hline FTO fiber area, $\mu \mathrm{m} 2$ & $4357.86 \pm 288.73$ & $3780.99 \pm 273.19$ & 0.05 \\
\hline FTG fiber area, $\mu \mathrm{m} 2$ & $3792.26 \pm 188.66$ & $3560.76 \pm 182.19$ & 0.35 \\
\hline Mean fiber area, $\mu \mathrm{m} 2$ & $4143.00 \pm 220.45$ & $3757.93 \pm 211.91$ & 0.15 \\
\hline
\end{tabular}

No significant differences were recorded in morphometrical characteristics of $m$. semitendinosus between gilts and barrows of German Landrace pigs. However, for all investigated traits (weight, length, diameter and cross sectional area of the muscle) higher values were obtained for gilts. The analysis of histological structure of this muscle showed significant differences due to gender. The average cross sectional area of muscle fibers was larger in barrows than in gilts, but a statistically significant difference $(p<0.05)$ was determined only for FTO fibers, which is in accordance with results of some authors [7-9], but contradictory to other authors [10-12]. An inverse relationship between the number and cross sectional area of muscle fibers was obtained. The total number of muscle fibers in the $m$. semitendinosus was significantly higher $(\mathrm{p}<0.01)$ in gilts, with muscle fibers of smaller cross sectional area.

The distribution of muscle fiber types in $m$. semitendinosus was not significantly different between genders, which is in accordance with results of other authors [7]. There is evidence of a significantly higher percentage of STO fibers in boars than in gilts, but these authors also state that castration leads to a decrease in the percentage of STO fibers [1]. In both gender FTG fibers are the most abundant (48-52\%), FTO fibers represented $27-30 \%$ of the total fiber number, and STO fibers were the least represented, with approximately $20 \%$, which is in accordance with results of other authors [12,16].

To conclude, gender did not influence morphometric characteristics of m. semitendinosus: weight, length, girth and cross sectional area. The analysis of histological structure of the muscle showed significant differences, where a higher total number of muscle fibers was observed in gilts $(\mathrm{p}<0.01)$. The cross sectional area of FTO fibers was significantly higher in barrows $(p<0.05)$. The distribution of muscle fiber types in 
m. semitendinosus did not differ significantly regarding to gender. Both in gilts and in barrows, fast twitch glycolitic FTG fibers were dominant, while the least represented were fibers of slow twitch oxidative STO type.

\section{Authors' contributions}

IB collecting of muscle samples, preparation of samples for histology, microscopy. DV and MB performed statistical analysis. IN and SJ translated article into english. $\mathrm{MZ}$ and $\mathrm{ZB}$ gathering of references from the field of investigation, formatting the article according to instructions for authors.

\section{Declaration of conflicting interests}

The author(s) declared no potential conflicts of interest with respect to the research, authorship, and/or publication of this article.

\section{REFERENCES}

1. Lefaucheur L, Gerrard D: Muscle fiber plasticity in farm mammals, J Anim Sci 2000, 77: 1-19.

2. Te Paas MFW, Everts ME, Haagsman HP: Muscle Development of Livestock Animals. Physiology, Genetics and Meat Quality, CABI Publishing, Wallingford, Oxfordshire, UK. 2004.

3. Sazil A, Parr T, Sensky P, Jones S, Bordsley R, Buttery P: The relationship between slow and fast myosin heavy chain content, calpastatin and meat tenderness in different ovine skeletal muscles, Meat Sci 2005, 69: 17-25.

4. Kirchofer K, Calkins C, Gwartney B: Fiber type composition of muscles of the beef chuch and round, J Anim Sci 2002, 80: 2872-2878.

5. Rehfeldt C, Stickland C, Fiedler I, Wegner J: Environmental and genetic factors as sources of variation in skeletal muscle fiber number, Basic Appl Myol 1999, 5: 235-253.

6. Ryu C, Choi M, Lee H, Shin G, Choe H, Kim M, Hong C, Kim C: Comparing the histochemical characteristics and meat quality traits of different pig breeds, Meat Sci 2008, 80: 363-369.

7. Wojtysiak D, Paściak P, Migdal W: The effect of sex on the histochemical profile of the $\mathrm{m}$. longissimus lumborum of pigs slaughtered at $130 \mathrm{~kg}$ body weight, Roczniki Naukowe Zootechniki 2003, 30 (2): 253-260.

8. Velotto S, Vitale C, Stassi T, Crasto A: New Insights into Muscle Fibre Types in Casertana Pig, Acta Veterinaria Brno 2010, 79: 169-176.

9. Okrouhlá M, Čitek J, Stupka R, Brzobohatý L, Vehovský K: The effect of gender on the characteristics of muscle fibers in pork, Journal of Central European Agriculture 2014, 15: 64-71.

10. Solomon B, Campbell R, Steele N: Effect of sex and exogenous porcine somatotropin on longissimus muscle fiber characteristics of growing pigs, J Anim Sci 1990, 68: 1176-1181. 
11. Larzul C, Lefaucheur L, Ecolan P, Gogue J, Talmant A, Sellie P, Monin G: 1997. Phenotypic and genetic parameters for Longissimus muscle fiber characteristics in relation to growth, carcass and meat quality traits in Large White pigs, J Anim Sci 1997, 75: 3126-3137.

12. Bee G: Effect of early gestation feeding, birth weight, and gender of progeny on muscle fiber characteristics of pigs at slaughter, J Anim Sci 2004, 82: 826-836.

13. Romeis B: Mikroskopische Technik. P. BÖCK (Ed.), Urban \& Schwarzenberg (696pp), München 1989, 110-120.

14. Novikoff AB, Shin W, Drucker J: Mitochondrial localization of oxidative enzymes staining results with two tetrazolium salts, J Biophys Biochem Cytol 1961, 9:47-61.

15. Guth L, Samaha FJ: Procedure for the histochemical demonstration of actomyosin ATPase, Exp Neurol 1970, 28:365-367.

16. Adamović I, Vitorović D, Blagojević M, Nešić I, Brkić Z: Histological and histochemical properties of $M$. semitendinosus in German Landrace pigs at birth and market weight, Acta Veterinaria Beograd 2014, 64 (3) , 319-326.

\section{POREĐENJE MORFOMETRIJSKIH I HISTOLOŠKIH OSOBINA M. SEMITENDINOSUS-A KOD NAZIMICA I KASTRATA NA ZAVRŠETKU TOVA}

BOŽIČKOVIĆ Ivana, VITOROVIĆ Duško, BLAGOJEVIĆ Miloš, NEŠIĆ Ivana, JOVIĆ Slavoljub, ZDRAVKOVIĆ Marija, BRKIĆ Zlata

Cilj ovog rada je bio da se ispita postojanje razlika u morfometrijskim osobinama i strukturi m.semitendinosus, između ženki i kastriranih mužjaka svinja Nemačkog landrasa, na kraju tova. Morfometrijske osobine (masa, dužina, obim i površina poprečnog preseka) m. semitendinosus, nisu bile statistički značajno različite između polova. Histološka analiza strukture mišića je pokazala da postoje neke razlike između polova. Ukupan broj mišićnih vlakana u $m$. semitendinosus bio je veoma značajno $(\mathrm{p}<0.01)$ veći kod ženki nego kod kastriranih mužjaka. Površina poprečnog preseka FTO vlakana bila statistički značajno veća $(\mathrm{p}<0.05)$ kod kastriranih mužjaka nego kod ženki. Procentualni udeo (zastupljenoost) tipova mišićnih vlakana u m.semitendinosus, se nije značajno razlikovao između polova. Kod oba pola najveći udeo (oko polovinu od svih tipova vlakana) su imala bela brzo kontrahujuća glikolitička (FTG) vlakana (48-52 \%). Od crvenih, oksidativnih vlakana najmanji udeo (20.23-20.68 \%) su imala sporo kontrahujuća (STO) vlakna dok su brzo kontrahujuća (FTO) vlakna bila zastupljena u većem procentu $(27-30 \%)$. 